\title{
Research on the Evolution and Influence of Employee Compensation Standards
}

\author{
Fang-fang Lang \\ International Business School \\ Shaanxi Normal University \\ Xi'an City, Shaanxi Province, China
}

\author{
Ping Zhang ${ }^{2}$ \\ International Business School \\ Shaanxi Normal University \\ Xi'an City, Shaanxi Province, China
}

\begin{abstract}
China began to implement new employee compensation standards in 2014, and the changes had certain impact on the management of enterprises. This paper describes the evolution process of employee compensation standards, and studies the progress and actual influence of employee compensation based on actual cases. The paper takes Yutong company as an example and uses its enterprise earnings data to analyze income, expenses, income tax, and financial situation changes, each content has a significant positive development, which is in line with superior places of the new standards. The research results show that the changes of the standards have a significant impact on the development of enterprises. At the same time, this paper also puts forward corresponding suggestions to improve the employee compensation standards.
\end{abstract}

Keywords-Employee Compensation; Evolution; Influence; Yutong company

\section{INTRODUCTION}

With the constant improvement of China's economic development, China proposes high demand of enterprises to account employee compensation. In practice, the form of employee compensation is diversified. In addition to the monetary form, the non-monetary form of remuneration also occupies a large proportion, so enterprises should comprehensively account employee compensation. Before and after the change of the standards, there will be a great impact on enterprises, which includes not only the accounting content of employee compensation, but also the costs and profits of the enterprise. As the standards improve, it will be more suitable to China's economic situation, and will greatly promote the development of enterprises.

\section{THE EVOLUTION OF EMPLOYEE COMPENSATION STANDARDS}

Before 2000, employee compensation was not contained in specific guidelines, nor was it clearly defined. Therefore, the worker wages in the balance sheet only embodied in "Accrued Payroll" and "Accrued Employee Benefits". Information about other wages cannot be disclosed, which was the drawback of the accounting measure of the employee compensation in that period.

On February 15th, 2006, China firstly promulgated employee compensation standards (hereinafter referred to as "the original standards").This standards provision: the employee compensation refers to various forms of compensation and other related expenses that the enterprise offers employees in order to access to services provided by them, thus there will be a clear statement of the concept, scope and content of employee compensation. Subsequently, "Accrued Employee Benefits" had been revised in the enterprise accounting standards, and belong to employee compensation. The accounting method of extraction before use was adopted, while the extraction ratio was reasonably determined according to the practical conditions in enterprises. That's to say, from January 1st, 2007, the standards canceled the clause that the enterprises raised employee welfare benefits on the basis of total salary $14 \%$ plan, which is an advance in employee compensation awareness.

In 2012, China proposed an amendment for employee compensation. This standardized the accounting measure of short-term salary and dismissal benefits. The main content of the amendment included enriching the post-resignation benefits, standardizing the accounting measure of short-term compensation and dismissal benefits and introducing other long-term employee benefits.

To further development and internationalization of Chinese enterprise accounting standards, the ministry of finance issued a revised enterprise accounting standards on January 27th, 2014.It also stipulated that the revised employee compensation standards should be implemented from July 1st, 2014 (hereinafter referred to as "the new standards").New standards provision: the employee compensation refers to all forms of remuneration or compensation that enterprises give employees and their relatives in order to access to their services. And it included short-term salary, post-employment benefits, dismissal benefits and other long-term employee benefits. Benefits provided to employees' spouses, children, dependents, dependent of deceased employees and other beneficiaries by the enterprise also belong to employee compensation [1].

\section{A BRIEF INTRODUCTION TO ALL ASPECTS OF NEW EMPLOYEE COMPENSATION STANDARDS}

Short-term salary is a general concept. It mainly accounts the salary that the enterprise need to pay when employees offer service. However, compensation for the termination of labor relations should be excluded. Compared with the original standards, short-term salary includes not only employee salaries but also short-term paid absences, short-term profit-sharing schemes and other short-term compensation.

Compensated absences, in other words, when the employee is absent from work normally, the enterprise still need to pay wages or provide compensation. It generally includes annual 
leave, sick leave, marriage leave, maternity leave and family leave. This is a kind of benefits that the employees should be entitled to, which reflects the humanization and rationalization of the standards at the same time.

Post-employment benefits are, during the employee's employment, what the enterprise and employees agree on and employees can enjoy after retirement. The enterprise should provide the corresponding remuneration and welfare for the employees during their employment and after their retirement, and the employees should also continue to provide services and create value for the enterprise after their retirement. This benefits are a good safeguard for the retired people's life.

Other long-term employee benefits are special and uncommon, which include long-term paid absence, long-term disability benefits, long-term profit-sharing plans, etc. In addition, the new standards also standardize the accounting measure of other long-term employee benefits.

In a word, the provisions of the new standards can promote the sustainable development of enterprises, and reintegrate the composition of enterprise labor costs, so as to mirror faithfully the situation of enterprises.

\section{CHANGES IN EMPLOYEE COMPENSATION STANDARDS}

\section{A. Changes in the employee compensation's content}

Firstly, employee compensation forms are diverse. In original standards, the content of employee compensation only accounts salary and welfare benefits, while new standards clearly point out that employee compensation includes many contents, such as worker wages, bonus, allowance, etc. This is not only formal diversification, but also more comprehensive in the aspect of content.

Secondly, the content of post-compensation benefits has been enriched. In the new standards, the concept of post-compensation benefits firstly cite the international financial reporting standards, and it is also classified as defined contribution plans and defined benefit plans [2]. Defined contribution plans are the expense that need to be paid before employee's retirement or unemployment by law. However, the defined benefit plans are a commercial or contractual supplementary pension or medical insurance payment plan. The new standards propose the concept of post-compensation benefits, and it also has a detailed classification, which not only standardizes the accounting measure of post-compensation benefits, but also makes Chinese enterprise accounting standards further convergence with the international community.

Thirdly, the accounting measure of welfare benefits is unified. There is no unified standard for the accounting method of employee welfare benefits in the original standards. The new standards stipulate that enterprises should withdraw employee welfare benefits in proportion to their total salary. It is accounted according to the beneficiaries, and recognized as employee pay payable. With regard to it, this paper takes Yutong company as an example. In the welfare statement, it briefly describes the types of enterprise welfare: indemnificatory welfare, monetary welfare, material welfare, housing compensation, etc.

Fourthly, compensated absences have been integrated. As for compensated absences, it was not explicitly mentioned in the original standards, but was distributed in the application guide and explanation, while the new standards incorporate the concept of compensated absences and its related provisions. Compensated absences are also classified as "cumulative paid absences" and "non-cumulative paid absences". According to the vacation system of Yutong company, employees who have worked for more than one year in succession can enjoy paid vacation for a certain period of time (5-15 days in terms of the length of service) every year, in addition to the unified vacation policy by the company.

Fifthly, the timing of recognizing dismissal benefits is specified in the new standards. In the original standards, the contents and accounting measure of dismissal benefits were only explained, and there was no clear time point for recognizing dismissal benefits, which would lead to be inconsistent with recognition time among enterprises. Although it has some flexibility, it will also lead to the arbitrariness of practical accounting treatment, and is not conducive to the comparison among enterprises and the development of enterprises themselves.

The new standards make it clear that when enterprises offer employees dismissal benefits, the dismissal benefits should be recognized as employee compensation and recorded in the current profits and losses. The time point for recognizing is an early date when the enterprises cannot unilaterally withdraw the dismissal benefits provided by the proposal of the termination of labor relations plan or reduction plan, or when the enterprises recognize the costs or expenses related to the reorganization involving the payment of dismissal benefits.

\section{B. Changes in the scope of employee compensation}

Firstly, the scope of "employees" in employee compensation is clarified. Following the principle of substance over form, the new standards highlight the scope of the employees. In other words, all personnel who actually provide services to the enterprises are included in the staff category.

The scope of "employees" in the new standards falls into three types. The first type is those who have signed formal employment contracts with company, including full-time, part-time and temporary workers. Secondly, they are key executives. Although they don't enter into labor contracts with enterprise, they are formally appointed by enterprise, which also should be attributed to the scope of employees in enterprise. Finally, although there is no formal labor contract with the enterprise, or the enterprise has no formal appointment, they do provide similar services in the enterprise [3].

Secondly, the application scope of employee compensation is extended. During the daily operation, not only the enterprise should provide various forms of remuneration to the employees in accordance with the regulations, but also provide benefits to the employees' spouses, children and dependents. This is more specific, more comprehensive than the original 
standards. And it accords with the development tendency of the modern enterprises.

\section{THE IMPACT OF EMPLOYEE COMPENSATION ACCOUNTING ON ENTERPRISES}

Compared with the original standards, the new standards not only expand the scope of employees, but also redefines the concept and content of employee compensation [4], and the accounting measure of various types of employee compensation also has obvious changes. These changes in the new standards will have a great impact on the financial statement items, expenses and benefits of the enterprise.

\section{A. The influence of changes on the financial statements items}

First of all, it can be able to find the difference from the financial statements of Yutong company. Before 2006 (including 2006), "Accrued Payroll" and "Accrued Employee Benefits" measure employee compensation in the balance sheet. After 2007, Yutong company changed the reporting item of employee compensation to "employee pay payable" according to the enterprise accounting standards issued in 2006.

Secondly, the accounting content of employee compensation before 2006 was not clear in the original standards, so the specific content of employee compensation cannot be detailed shown in the balance sheet. From 2007 to 2011, Yutong company made it clear that employee compensation included wages, bonuses, allowances and subsidies, employee welfare, social insurance and housing accumulation fund, union funds, employee education funds and non-monetary benefits (the compensation due to terminate the labor relationship ), etc. In 2012, the accounting content of employee compensation increased the disability fund item. In 2014, Yutong company clearly stated in the balance sheet that employee compensation payable included short-term salary, post-employment benefits (defined contribution plan), and dismissal benefits. This is the reason why Yutong company has made corresponding adjustments in accordance with the provisions of the standards, and the constituent part of employee compensation has changed a lot.

It can be seen that every minor change in the standards has different influence in a degree on enterprises, and also represents the progress and development of the accounting treatment of employee compensation.

\section{B. The influence of changes on earnings}

Firstly, social insurance premium in employee compensation has an impact on enterprise income. The original standards stipulated that five social insurance and one housing fund, staff education funds, union funds are directly included in the current profits and losses. However, the new standards stipulate that employee compensation that is not included in cost should be included in current profits and losses. In addition, different departments should be differentiated for accounting treatment, which will contribute to greatly reduce the current collection expenses amount in enterprises[5], especially the administrative expenses will be drastically reduced, and the current costs amount will be reduced in the income statement, so as to give rise to greatly increase the enterprise income.

As can be seen from the annual report of Yutong company in 2014 (as shown in table I), selling expenses and administrative expenses contain the amount carried forward of employee compensation. This exactly reflects that the employee compensation is recognized as liabilities, and is included into the current expenses by the beneficiaries.

The annual report of 2013 is shown in table II. Compared with table I and table II, it is observed that the amount of selling expenses and administrative expenses in 2014 markedly increase, which is higher than that in 2013.

TABLE I. SELLING EXPENSES AND ADMINISTRATIVE EXPENSES IN 2014

Selling expenses

\begin{tabular}{|c|c|c|}
\hline Item & Current amount & Previous amount \\
\hline Employee compensation & $246,231,709.19$ & $160,112,066.40$ \\
\hline Travel expenses & $228,009,046.83$ & $191,663,893.39$ \\
\hline Business entertainment & $56,235,222.28$ & $58,771,686.48$ \\
\hline$\ldots$ & $\ldots$ & $\ldots$ \\
\hline Total & $1,149,954,983.39$ & $927,571,001.59$ \\
\hline
\end{tabular}

\begin{tabular}{|c|c|c|} 
Administrative expenses \\
\begin{tabular}{|c|c|c|}
\hline Item & Current amount & Previous amount \\
\hline Employee compensation & $351,500,834.98$ & $287,051,175.32$ \\
\hline Depreciation cost & $43,820,580.80$ & $34,836,136.21$ \\
\hline Travel expenses & $18,839,975.72$ & $16,187,045.76$ \\
\hline Business entertainment & $15,095,505.10$ & $16,192,014.79$ \\
\hline$\ldots$ & $\ldots$ & $\ldots$ \\
\hline Total & $880,513,246.49$ & $698,998,678.26$ \\
\hline
\end{tabular}
\end{tabular}

TABLE II. SELLING EXPENSES AND ADMINISTRATIVE EXPENSES IN 2013

Selling expenses

\begin{tabular}{|c|c|c|}
\hline Item & Current amount & Previous amount \\
\hline Employee compensation & $248,052,745.37$ & $246,231,709.19$ \\
\hline Travel expenses & $252,625,559.18$ & $228,009,046.83$ \\
\hline advertising and publicity cost & $42,703,236.23$ & $50,200,768.75$ \\
\hline$\ldots$ & $\ldots$ & $\ldots$ \\
\hline Total & $1,241,389,817.24$ & $1,149,954,983.39$ \\
\hline
\end{tabular}

Administrative expenses
\begin{tabular}{|c|c|c|}
\hline Item & Current amount & Previous amount \\
\hline Employee compensation & $490,197,447.21$ & $351,500,834.98$ \\
\hline Depreciation cost & $65,157,577.53$ & $43,820,580.80$ \\
\hline Travel expenses & $15,644,599.59$ & $18,839,975.72$ \\
\hline Business entertainment & $8,807,258.85$ & $15,095,505.10$ \\
\hline$\ldots$ & $\ldots$ & $\ldots$ \\
\hline Total & $1,071,030,306.22$ & $880,513,246.49$ \\
\hline
\end{tabular}

Secondly, expenses and benefits of enterprise are affected by the changes. The new standards stipulate that the dismissal benefits is a part of the employee compensation, while the original standards think the dismissal benefits should be recognized as accrued liability. Therefore, compared with accrued liability, employee compensation may be recognized as expenses in advance than before, resulting in the increase of current expenses and the decrease of enterprise current income [6]. 


\section{The influence of changes on income tax expenses}

According to the above analysis, the changes of the original and new accounting standards lead to the fluctuation of the operating profit, then total profit also make a difference, consequently it results in different income tax expenses, and the enterprise's net income will also vary.

Without considering other matters and other tax adjustments, according to different beneficiaries, all kinds of employee compensation are respectively included in cost or current profits and losses. Compared with the original standards, the current income of enterprise increased, income tax expenses also increased. However, as inventory costs are transferred to operating costs in subsequent periods, and the depreciation or amortization of assets is carried forward to the management expense, then the expenses of each subsequent period will increase, the operating profit and the income tax expense will also decrease [7][6].

In Yutong's 2007 financial statement (as shown in table III), because of the implementation of the accounting standards issued in 2006, it is necessary to adjust the amount of employee compensation payable. Thereinto, the balance of unused welfare benefits that plans to withdraw is adjusted in that period, which caused the increase of profit at the same time.

TABLE III. VARIANCE ADJUSTMENT TABLE OF 2007NET PROFIT AND 2006 NET PROFIT

\begin{tabular}{|c|c|}
\hline Item & Amount \\
\hline ... & ... \\
\hline The total number of other items impacts & $6,285,314.74$ \\
\hline Among them: 1. Employee benefits payable ${ }^{a}$ & $6,285,314.74$ \\
\hline 2. Increase gain on other capital reserves & \\
\hline Simulated net profit for 2006 & $233,377,177.48$ \\
\hline
\end{tabular}

a. Assuming that the new accounting standards will be fully implemented in 2006, the balance of unused employee welfare funds after being deducted from the income tax.

B. Strengthen to carry out the new standards

\section{CONCLUSION}

The content of the new standards is gradually geared to international standards, which indicates that China is exploring accounting standards more in line with China's national conditions and improving Chinese enterprise accounting standards. Changes in the content of the standards will have different impacts on enterprises. This paper takes Yutong company as an example to analyze the impact of the evolution of the employee compensation standards on enterprises. The research results show that the changes of the standards make enterprises disclose the employee compensation items in more detail, and make the management of enterprise expenses more standardized, which affects the income and income tax.

With the development of Chinese market economy, the enterprise accounting standards will be constantly updated and more suitable with the development of enterprises in China, and also play a positive guiding role in the accounting method of employee compensation. However, the new standards are not perfect enough, therefore, several suggestions are put forward in this paper.

\section{A. Further refinement of non-monetary benefits}

There are many types of non-monetary benefits. However, due to the inconsistent accounting procedure, enterprises may increase costs and offset tax through speculation. In order to prevent this phenomenon, it is suggested to make a reasonable explanation in the information disclosure of the financial reports, which will prevent the occurrence of false events. In addition, the accounting method of non-monetary benefits should be further refined. It is necessary to consider the operability and maintain a certain flexibility and variability.
The new standards are the complement and further specification to the original standards. Therefore, enterprises should actively carry out and guide practical work in accordance with the provisions of the new standards. If the deficiencies of the standards are found in practice, the relevant departments should be informed of the situation in a timely manner, so as to improve the employee compensation standards.

\section{REFERENCE}

[1] Che Jingping. A study on the impact of changes in the standards of employees' compensation on enterprises, J. Accounting Learning,22 (2017) 186-187.(In Chinese)

[2] Wang Hua. Effects of new and revised accounting standards and supplementary provisions on corporate finance, J..Communication of Finance and Accounting, 17 (2014) 126-127.(In Chinese)

[3] Lei Yunfeng. A brief analysis of the new changes in the compensation standards of employees and their impact on enterprises, J.China Business Update,14 (2014) 265.(In Chinese)

[4] Zhi Ninwa, Qin Jialong. Related accounting and influence analysis of new employee compensation accounting standards, J.Commercial Accounting,23 (2016) 31-33.(In Chinese)

[5] Yan Yuying. The influence of the new standards on the compensation management of state-owned enterprises, J.Modern Business, 4 (2014) 90-91. (In Chinese)

[6] Xiong Yan. The new standard of compensation accounting and its impact on enterprise assets, profit and loss, J.Friends of Accounting,5 (2008) 75-76.(In Chinese)

[7] Yu Kui. An analysis of the differences between the tax rates and the adjustment of the tax rates, J.Taxation Research, 1 (2016) 63-68. (In Chinese) 